\title{
Economic and Environmental Impact of Pesticide Use in Conventional Cotton and Bt Cotton
}

\author{
P. Indhu Kavi*, J.S. Amarnath and B. Sivasankari
}

Department of Agricultural Economics, Agricultural College and Research Institute, Tamil Nadu Agricultural University, Madurai, Tamil Nadu, India

Corresponding author: indhukavi.geetha@gmail.com

\begin{abstract}
The present study studies the environmental and health effects of chemical pesticide use and quantified by using the Environmental impact quotient method (Kovach 1992). In order to compare the Environmental impact quotient (EIQ) a study was made on Bt and conventional cotton farmers in Dharmapuri district of Tamil Nadu. The study revealed that bollworm incidence was highly reduced in Bt cotton cultivation especially in fruiting stage of American bollworm and Pink bollworm. The quantity and frequency of pesticide application was also reduced in Bt cotton cultivation especially the quantity with a proportion of 93.61 per cent. The expenditure for the pesticides was high in conventional cotton as compared to Bt cotton by 77.19 per cent. The perception of farmers towards economic, environmental and social aspects favoured Bt cotton. The total environmental impact for conventional cotton with EIQ field rating was 157.76. The total environmental impact for Bt cotton with EIQ field rating was 16.23. Total environmental impact for pesticides in Bt cotton was low by 89.52 per cent as compared to conventional cotton due to the reduction of pesticides used for controlling Bollworm in Bt cotton. Hence farmers have to be educated about the ill effects of over use of plant protection chemicals in conventional cotton and to adopt the Bt farming technology to reduce the effect of pesticides on environment and ecosystem by conducting awareness programmes and crop seminars by the Agriculture Department.
\end{abstract}

Keywords: Conventional cotton, Bt cotton, American Bollworm, Pink Bollworm, Environmental Impact Quotient (EIQ), EIQ field rating

Bt cotton is a Genetically modified crop that makes the cotton plant resistant to certain pests by the insertion of genes from the soil bacterium Bacillus thuringiensis (Bt). Bt cotton was first commercialized in U.S.A in the mid 1990"s and subsequently in the other countries including china, India and Pakistan. Major cotton producers of India and Pakistan accounts for 50 per cent of all pesticides used in agriculture and covering 15 per cent of the crop land area of cotton. Several studies revealed that Bt cotton reduced pesticide usage and increased cotton yields and environmental and health benefits to the farmers (Huang et al. 2002 and Bennett et al. 2004). Global cotton production releases 220 metric tons (MT) of carbon dioxide every year with $1 \mathrm{MT}$ of non organic cotton fiber producing 1.8 MT of carbon dioxide. According to a recent joint FAO, UNEP, and WHO publication, between 26 million (1per cent) and 77 million ( 3 per cent) of agricultural workers worldwide suffer from acute poisonings, with at least 1 million requiring hospitalization every year. As cotton is one of the most heavily sprayed agriculture crops throughout the world and pesticides sprays were reduced by the adoption of $\mathrm{Bt}$ cotton lead to sizeable reduction of environmental damage. Therefore it is essential; to critically examine the environmental and health benefits in the adoption of Bt cotton and hence this study conducted in Dharmapuri district of Tamil Nadu.

\section{METHODOLOGY}

The study area covers the Dharmapuri district of Tamil Nadu consisting of five blocks and out of 
which two blocks of Pappireddipatty and Harur occupy the predominant area of cotton in that district and these blocks were selected. From the selected blocks, three villages in each block were selected purposively. Finally 20 cotton growing farmers and of which, 10 farmers cultivating conventional cotton and 10 farmers cultivating $\mathrm{Bt}$ cotton from each village were selected at random and totally 120 farmers were selected for the study. Thus multi stage random sampling method was adopted for this study. The study observed that majority of the conventional cotton farmers were growing extra long varieties of MCU-5,MCU-12 and MCU-13. The major Bt hybrids growing in that district were $\mathrm{RCH}-2, \mathrm{RCH}-20$ and Jackpot.

The data obtained were analyzed by using the Environmental Impact quotient method developed by Kovach et al. (1992). EIQ has three components is based on the three potentially effected elements of the farm worker, the consumer, and the ecology. The EIQ measures the impact of the active ingredient in each pesticide by assigning an equal weight to each of its three components and has a scale of 1 to 5 . Factor carrying the highest weight were multiplied by five, medium-impact factors were multiplied by three and those factors considered to have the least impact multiplied by one. The formula for determining the EIQ values for individual pesticide is given below and is the average of the farm worker, consumer and ecological components.

$$
\begin{gathered}
\mathrm{EIQ}=\left\{\mathrm{C}\left[\left(\mathrm{DT}^{*} 5\right)+\left(\mathrm{DT}^{*} \mathrm{P}\right)\right]+\left[\left(\mathrm{C}^{*}((\mathrm{~S}+\mathrm{P}) / 2)^{*} \mathrm{SY}\right)+\right.\right. \\
(\mathrm{L})]+\left[\left(\mathrm{F}^{*} \mathrm{R}\right)+\left(\mathrm{D}^{*}((\mathrm{~S}+\mathrm{P}) / 2)^{*} 3\right)+\right. \\
\left.\left.\left(\mathrm{Z}^{*} \mathrm{P}^{*} 3\right)+\left(\mathrm{B}^{*} \mathrm{P}^{*} 5\right)\right]\right\} / 3
\end{gathered}
$$

Where,

$$
\begin{aligned}
& \text { DT }=\text { Dermal Toxicity } \\
& \text { C }=\text { Chronic Toxicity } \\
& \text { SY }=\text { Systematicity } \\
& \text { F }=\text { Fish Toxicity } \\
& \text { L }=\text { Leaching potential } \\
& \text { R }=\text { Surface Loss potential } \\
& \text { D }=\text { Bird Toxicity } \\
& \text { S }=\text { Soil Half Life } \\
& Z \quad=\text { bee Toxicity } \\
& B \quad=\text { Beneficial arthropod Toxicity } \\
& \text { P }=\text { Plant surface half life }
\end{aligned}
$$

Farm worker's risk was defined as the sum of applicators exposure $(\mathrm{DT} \times 5)$ plus labour exposure $(\mathrm{DT} \times \mathrm{P})$ times the long term health benefits or chronic toxicity (C). Within the farm worker component, applicator exposure was determined by multiplying the Dermal toxicity (DT) rating to small laboratory mammals (rabbits or rats) times a coefficient of five to count for the increased risk associated with handling concentrated pesticides. Harvester exposure was equal to Dermal toxicity (DT) times the rating for plant surface residue half life potential ( the time required for one half of the active ingredient to breakdown.

The consumer component was the sum of consumer exposure potential $(\mathrm{Cx}((\mathrm{S}+\mathrm{P}) / 2 \times \mathrm{SY})$ plus the potential ground water effects $(\mathrm{L})$. Ground water effects are placed in the consumer component because they were more of a human health issue (contamination of drinking well water) then a wildlife issue. Consumer exposure was calculated as chronic toxicity $(\mathrm{C})$ times the average for residue potential in soil and plant surfaces (because roots and other plant parts are eaten) times the systematic potential rating of the pesticide) the pesticides ability to be absorbed by the plants.

The ecological component of the model was comprised of aquatic and terrestrial effects and was the sum of effects of the chemicals on fish $\left(\mathrm{F}^{*} \mathrm{R}\right)$, birds (Dx $((\mathrm{S}+\mathrm{P}) / 2) \times 3)$ and beneficial arthropods $(B x P \times 5)$. The environmental impact of pesticides on aquatic system was determined by multiplying the chemical toxicity to fish rating times the surface runoff potential of the specific pesticide (the runoff potential takes into account the half life of the chemical in surface water.

The impact of pesticides on terrestrial systems was determined by summing the toxicities of the chemicals to birds, bees and beneficial arthropods. Because terrestrial organisms were more likely to occur in commercial agricultural settings than fish, more weight was given to the pesticidal effects on these terrestrial organisms. Impact on birds was measured by multiplying the rating of toxicity to birds by the average half life on plant and soil surfaces times three. The effect on beneficial arthropods was determined by taking the pesticide toxicity rating to beneficial natural enemies' times the half-life on plant surfaces times five. 
To account for different formulations of the same active ingredient and different use patterns a simple equation called EIQ field use Rating was developed.

EIQ Field Use Rating $=$ EIQ $\times$ per cent of active ingredient $\times$ Rate

\section{RESULTS AND DISCUSSION}

\section{Incidence of Bollworm in flowering stage and fruiting stage (\%)}

The percentage of incidence of Bollworm in flowering stage and fruiting stage in conventional cotton and Bt cotton is furnished in the Table 1. It could be observed from the table that the incidence of bollworm was high in conventional cotton as compared to Bt cotton especially in fruiting stage rather than flowering stage. Further among different bollworms, American bollworm incidence was very less in fruiting stage with a proportion of 21.53 per cent in Bt cotton followed by pink bollworm with 16.58 per cent and spotted bollworm with 0.47 per cent. The incidence of American bollworm in flowering stage was 0.89 per cent less in Bt cotton followed by pink bollworm with 0.36 per cent and spotted bollworm with 4.12 per cent. Thus it could be concluded from the table that bollworm incidence was highly reduced in Bt cotton cultivation especially in fruiting stage and that too in American bollworm and Pink bollworm incidences.

\section{Frequency and quantity of pesticides application}

The frequency and quantity of pesticides application in conventional cotton and Bt cotton is furnished in the Table 2.

It could be observed from the table that the quantity of pesticide application was lower in Bt cotton by 93.61 per cent and the frequency of pesticide application was also lower in Bt cotton by 75.00 per cent as compared to conventional cotton. With regard to individual pesticides, the quantity and frequency of pesticide application of Dimethoate was 33.33 per cent each less in Bt cotton as compared to conventional cotton. In Imidachloprid, the quantity and frequency of pesticide application was same in both conventional cotton and Bt cotton. The insecticides such as Chlortraniliprole, Methomyl, Fenvalrate, Acephate and Emamectin benzoate were used only for conventional cotton to control bollworms. Thus it could be concluded from the table that quantity and frequency of pesticide application was reduced with Bt cotton cultivation

Table 1: Incidence of Bollworm in conventional cotton and Bt cotton (\%)

\begin{tabular}{|c|c|c|c|c|c|c|c|}
\hline \multirow[t]{2}{*}{ S1. No. } & \multirow[t]{2}{*}{ Bollworm } & \multicolumn{2}{|c|}{ Flowering stage } & \multirow[t]{2}{*}{$\%$ diff } & \multicolumn{2}{|c|}{ Fruiting stage } & \multirow[t]{2}{*}{$\%$ diff } \\
\hline & & Conventional cotton & Bt cotton & & $\begin{array}{c}\text { Conventional } \\
\text { cotton }\end{array}$ & $\begin{array}{c}\mathrm{Bt} \\
\text { cotton }\end{array}$ & \\
\hline 2 & Pink bollworm & 0.68 & 0.32 & -0.36 & 18.60 & 2.02 & -16.58 \\
\hline 3 & Spotted bollworm & 5.62 & 1.50 & -4.12 & 0.73 & 0.26 & -0.47 \\
\hline
\end{tabular}

Table 2: Frequency and quantity of pesticides application

\begin{tabular}{|c|c|c|c|c|c|c|c|}
\hline \multirow{2}{*}{ S1. No. } & \multirow{2}{*}{ Pesticides } & \multicolumn{2}{|c|}{$\begin{array}{l}\text { Quantity of pesticide } \\
\text { application (liters/ha) }\end{array}$} & \multirow{2}{*}{$\%$ diff } & \multicolumn{2}{|c|}{$\begin{array}{l}\text { Frequency of pesticide } \\
\text { application ( no of sprays/ ha) }\end{array}$} & \multirow{2}{*}{$\%$ diff } \\
\hline & & $\begin{array}{c}\text { Conventional } \\
\text { cotton }\end{array}$ & Bt cotton & & $\begin{array}{c}\text { Conventional } \\
\text { cotton }\end{array}$ & Bt cotton & \\
\hline 1 & Dimethoate & 0.75 & 0.50 & 33.33 & 3 & 2 & 33.33 \\
\hline 2 & Imidachloprid & 0.25 & 0.25 & 0.00 & 1 & 1 & 0.00 \\
\hline 3 & Chlorontraniliprole & 1.75 & - & - & 2 & - & - \\
\hline 5 & Fenvalrate & 3.00 & - & - & 2 & - & - \\
\hline 6 & Acephate & 1.50 & - & - & 2 & - & - \\
\hline \multirow[t]{2}{*}{7} & Emamectin benzoate & 3.00 & - & - & 1 & - & - \\
\hline & Total & 11.75 & 0.75 & 93.61 & 12 & 3 & 75.00 \\
\hline
\end{tabular}


especially the quantity with a proportion of 93.61 per cent.

\section{Expenditure of Pesticides (₹/ ha)}

The chemical group and mode of action and expenditure for the pesticides used in conventional cotton and Bt cotton is furnished in the Table 3.

It could be observed from the table that the expenditure for the pesticides was reduced by 77.19 per cent in Bt cotton as compared to conventional cotton. Expenditure of pesticides for the systemic pesticide dimethoate was 33.33 per cent less in $\mathrm{Bt}$ cotton. The expenditure for the systemic insecticide imidachloprid was similar in both conventional cotton and Bt cotton. The systemic insecticides of methomyl and acephate and non systemic insecticides of chlortraniliprole, fenvalrate and emamectin benzoate was used only in conventional cotton. Thus it could be concluded from the table that the expenditure for the pesticides was high in conventional cotton as compared to Bt cotton and the per cent difference was 77.19 per cent.

\section{Farmers perception towards Economic, Environmental and Social aspects}

\section{Farmers perception towards economic aspects}

The comparative analysis of $\mathrm{Bt}$ and non $\mathrm{Bt}$ cotton farmers with respect to their perception towards economic aspects is presented in the table 4 . It could be observed from the table regarding good crop yield, Bt cotton response with 93.00 per cent as compared to conventional cotton respondents with 30.00 per cent which confirmed the success of Bt cotton. Similar studies conducted by Lalitha et al. showed that crop yield is good for Bt cotton respondents as compared to conventional cotton respondents Regarding market price for cotton, it is almost same high proportion for both Bt cotton and conventional cotton respondents with $\mathrm{Bt}$ cotton proportion of 75.00 per cent as compared to conventional cotton with a proportion of 71.67 per cent. More credit was needed for conventional cotton respondents with 66.67 per cent as compared to Bt cotton respondents with 41.67 per cent. Thus

Table 3: Expenditure of pesticides (₹/ ha)

\begin{tabular}{|c|c|c|c|c|c|c|}
\hline \multirow[b]{2}{*}{ Sl. No. } & \multirow[b]{2}{*}{ Pesticides } & \multirow[b]{2}{*}{$\begin{array}{l}\text { Mode of } \\
\text { action }\end{array}$} & \multirow[b]{2}{*}{ Chemical group } & \multicolumn{2}{|c|}{ Expenditure ( Rs / ha) } & \multirow[b]{2}{*}{$\%$ difference } \\
\hline & & & & $\begin{array}{l}\text { Conventional } \\
\text { cotton }\end{array}$ & $\begin{array}{c}\text { Bt } \\
\text { cotton }\end{array}$ & \\
\hline 1 & Dimethoate & Systemic & Organophosphate & 1800 & 1200 & 33.33 \\
\hline 2 & Imidachloprid & Systemic & Nionicotinoids & 750 & 750 & 0.00 \\
\hline 3 & Chlortraniliprole & Non systemic & Anthranilicdiamides & 1250 & - & - \\
\hline 4 & Methomyl & Systemic & Carbamate & 900 & - & - \\
\hline 5 & Fenvalrate & Non systemic & Synthetic pyrethroids & 1650 & - & - \\
\hline 6 & Acephate & Systemic & Organophosphate & 1400 & - & - \\
\hline 7 & Emamectin benzoate & Non systemic & Avermectin & 800 & - & - \\
\hline \multicolumn{4}{|c|}{ Total expenditure } & 8550 & 1950 & 77.19 \\
\hline
\end{tabular}

Table 4: Farmers perception towards Economic, Environmental and Social aspects

\begin{tabular}{|c|c|c|c|c|c|}
\hline \multirow{2}{*}{ Sl. No. } & \multirow{2}{*}{ Particulars } & \multicolumn{2}{|c|}{ Bt cotton respondents } & \multicolumn{2}{|c|}{ Conventional cotton respondents } \\
\hline & & No & Percentage & No & Percentage \\
\hline \multicolumn{6}{|c|}{ Economic aspects } \\
\hline \multirow[t]{3}{*}{1} & Regarding good crop yield & & & & \\
\hline & Yes & 56 & 93.33 & 18 & 30.00 \\
\hline & No & 4 & 6.67 & 42 & 70.00 \\
\hline \multirow[t]{3}{*}{2} & Regarding good market pric & $\mathrm{r} \operatorname{cott}$ & & & \\
\hline & Yes & 45 & 75.00 & 43 & 71.67 \\
\hline & No & 15 & 25.00 & 17 & 28.33 \\
\hline \multirow[t]{3}{*}{3} & For more credit, the respond & s bor & bank & & \\
\hline & Yes & 35 & 41.67 & 40 & 66.67 \\
\hline & No & 25 & 58.33 & 20 & 33.33 \\
\hline
\end{tabular}


Environmental aspects

1 Bt cotton cause harmful effect on environment

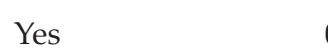

$0 \quad 0.00$

26.67

0

0.00

No 16

73.33

8

13.33

Don't know

44

52

86.67

2 Pesticides have a negative effect on environment

$\begin{array}{lll}\text { Yes } & 12 & \mathbf{2 0 . 0 0}\end{array}$

0.00

5.00

No

0

80.00

3

0.00

Don't know

48

0

95.00

3

Bt cotton effects on soil

Yes

16

26.67

57

13.33

No

0

0.00

Don't know

44

73.33

0.00

86.67

Social aspects

1

Reduction of Bollworm

Yes

57

95.00

3.33

No

3

5.00

2

96.77

2

Pest has controlled as compared to conventional cotton

$\begin{array}{lll}\text { Yes } & 54 & \mathbf{9 0 . 0 0}\end{array}$

$\begin{array}{lll}\text { No } & 6 & 10.00\end{array}$

$10.00 \quad 59$

1.67

98.33

the farmers' perception towards economic aspects favoured Bt cotton.

\section{Farmers perception towards environmental aspects}

The comparative analysis of Bt cotton and conventional cotton respondents with respect to farmers perception towards environmental aspects is presented in the table 4 . It could be observed from the table that 26.67 per cent of the Bt cotton farmers were revealed that there were no harmful effects on the cultivation of Bt cotton. In Bt cotton 20.00 per cent of the farmers were revealed that pesticides have a negative effect on environment. Similar studies conducted by lalitha et al. showed that both the Bt cotton and conventional cotton farmers don't know about the problems caused by the pesticide to the environment. Thus 26.67 per cent of the farmers revealed that Bt cotton effects soil and it reduces the soil fertility. Thus it could be concluded from the table that Bt cotton have no harmful effects to human beings but it slightly fertility status of the soil.

\section{Farmers perception towards social aspects}

The comparative analysis of Bt cotton and conventional cotton respondents with respect to farmers perception towards social aspects is presented in the table 4 . It could be observed from the table that reduction of bollworm is high in $\mathrm{Bt}$ cotton with 95.00 per cent whereas it is very less in conventional cotton with 3.33 per cent. The pest has controlled in Bt cotton with 90.00 per cent whereas it is only 1.67 per cent in conventional cotton. Similar studies conducted by Lalitha et al showed that the pest was controlled by Bt cotton whereas it is not controlled by conventional cotton.

\section{Environmental impact Quotient (EIQ) and EIQ field rating for conventional cotton}

The Environmental impact quotient (EIQ) scoring system for pesticides used in cotton was worked out based on the rating system developed by Kovach in 1992. Based on the scoring system EIO and EIQ field rating was worked out for conventional cotton and the results are furnished in the table 5 and Fig. 1.

To accurately compare pesticides and pest management strategies, the dose, the formulation or per cent active ingredient of the product and the frequency of pesticide application needs to be determined in conventional cotton and Bt cotton.

It could be observed from the table that environmental impact quotient was high for the 
Table 5: EIQ and EIQ field rating for conventional cotton

\begin{tabular}{cccccc}
\hline Sl. No. & Common name & EIQ & Active ingredient & $\begin{array}{c}\text { Application rate } \\
\text { (litres / ha) }\end{array}$ & EIQ field rating \\
\hline 1 & Dimethoate & 97.33 & 0.30 & 1.0 & 29.19 \\
2 & Imidachlorprid & 43.00 & 0.18 & 0.25 & 1.935 \\
3 & Chlorantraniliprole & 63.66 & 0.35 & 1.75 & 38.99 \\
4 & Methomyl & 22.66 & 0.90 & 1.5 & 30.59 \\
5 & Fenvalrate & 53.33 & 0.20 & 3.0 & 32.00 \\
6 & Acephate & 14.00 & 0.75 & 1.5 & 15.75 \\
7 & Emamectin benzoate & 31,00 & 0.10 & 3.0 & 9.30 \\
\hline Total & & $\mathbf{3 2 4 . 9 8}$ & & & $\mathbf{1 5 7 . 7 6}$ \\
\hline
\end{tabular}

chemicals dimethoate and chlortraniliprole but EIQ field rating was low due to the presence of less active ingredient content in dimethoate and chlortraniliprole. EIQ field rating for imidachloprid, ssssemamectin benzoate and acephate was low due to less active ingredient and application rate. EIQ field rating for methomyl and fenvalrate was comparatively high due to higher application rate. The total environmental impact for conventional cotton with EIQ field rating was 157.76.

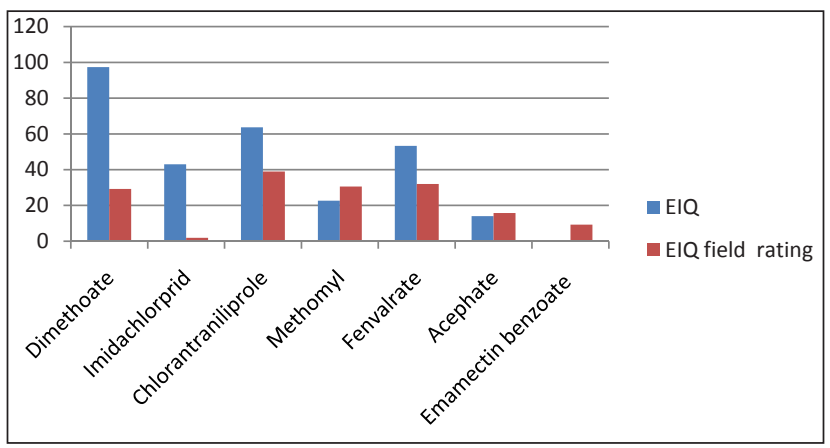

Fig 1: EIQ and EIQ field rating for conventional cotton

\section{EIQ and EIQ field rating for Bt cotton}

The environmental impact quotient field rating was worked out for Bt cotton and the results are furnished in the Table 6 and Fig. 2.

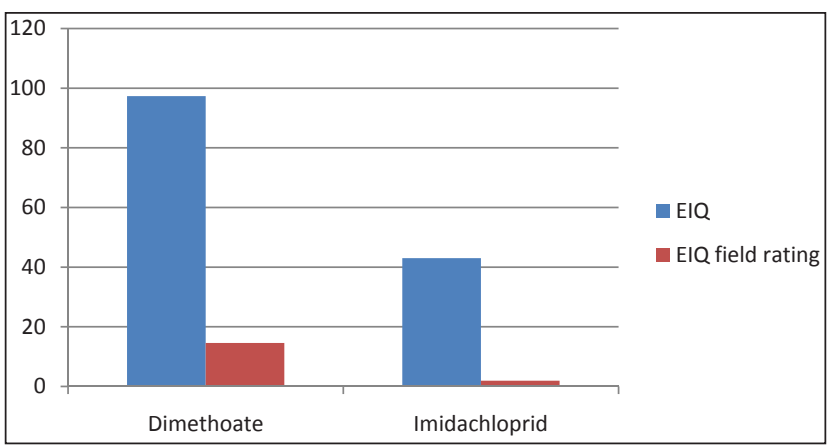

Fig 2: EIQ and EIQ field rating for Bt cotton

Environmental impact quotient was worked out for major pesticides used in Bt cotton such as dimethoate and imidachloprid. EIQ was high for dimethoate but the EIQ field rating was low due to the lower active ingredient and application rate. The EIQ field rating was low for imidachloprid and nonhazardous to the environment compared to other pesticides.

The total environmental impact for Bt cotton with EIQ field rating was 16.23. Total environmental impact for pesticides in Bt cotton was low by 89.52 per cent compared to conventional cotton due to the reduction of pesticides used for controlling Bollworm in Bt cotton.

Table 6: Environmental impact quotient (EIQ) and EIQ field rating for Bt cotton

\begin{tabular}{cccccc}
\hline Sl. No. & Common name & EIQ & $\begin{array}{c}\text { Active } \\
\text { ingredient }\end{array}$ & $\begin{array}{c}\text { Application rate } \\
\text { (litres / ha) }\end{array}$ & EIQ field rating \\
\hline 1 & Dimethoate & 97.33 & 0.30 & 0.50 & 14.59 \\
2 & Imidachloprid & 43.00 & 0.18 & 0.25 & 1.94 \\
\hline
\end{tabular}




\section{Policy implication}

The study revealed that environmental impact of pesticides with EIQ and EIQ field rating used in conventional cotton was high as compared to Bt cotton by a proportion of 89.52 per cent. Hence farmers have to be educated about the ill effects of over use of plant protection chemicals in conventional cotton and to adopt the Bt farming technology to reduce the effect of pesticides on environment and ecosystem by conducting awareness programmes and crop seminars by the Agriculture Department.

\section{REFERENCES}

Bennett, R., Ismael, Y., Morse, S. and Shankar, B. 2004. 'Reductions in insecticide use from adoption of Bt cotton in South Africa: Impacts on economic performance and toxic load to the environment', The Journal of Agricultural Science, 142: 665-674.

Huang, J., Hu, R., Rozelle, S., Qiao, F. and Pray, C. 2002. 'Transgenic varieties and productivity of small-holder cotton farmers in China', Australian Journal of Agricultural and Resource Economics, 46: 367-387.

Kovach, J., Petzoldt, C., Degni, J. and Tette, J. '1992. A method to measure the environmental impact of pesticides', in New York's Food and Life Sciences Bulletin: New York State Agricultural Experiment Station, No. 139 (Ithaca: Cornell University, pp. 1-8). 
